\title{
Divorce Records: Linn County, Iowa, 1928-1944
}

\author{
GLENDA RiLeY
}

DURING THE PAST DECADE, a growing interest in the history of divorce in the United States has encouraged researchers to begin retrieving information from dusty and faded county divorce records. From these sources, historians and social scientists have formulated suggestive theories about such issues as shifting gender relations, rising expectations of marriage, and the growth of companionate marriage. ${ }^{1}$

Clearly, divorce records are rich resources, but they are also extremely difficult to interpret. At best, they reveal only fragmentary reality regarding the people and the marriages they represent. For a number of reasons, the true and complete experiences, emotions, and motives of divorce-seekers often remain more clouded than exposed by divorce records.

Divorce documents from Linn County, Iowa, between 1928 and 1944 reveal many of the difficulties, and some of the

I would like to thank the Henry E. Huntington Library in San Marino, California, and the University of Northern Iowa for research support during 1988-89, and the staff of the Clerk of Courts Office, Civil Division, in Cedar Rapids for its assistance.

1. See, for example, Nancy F. Cott, "Divorce and the Changing Status of Women in Eighteenth-Century Massachusetts," William and Mary Quarterly 33 (1976), 586-614; idem, "Eighteenth-Century Family and Social Life Revealed in Massachusetts Divorce Records," Journal of Social History 10 (1976), 20-43; Robert L. Griswold, "Apart but Not Adrift: Wives, Divorce, and Independence in California, 1850-1890," Pacific Historical Review 49 (1980), 265-83; idem, Family and Divorce in California, 1850-1890 (Albany, NY, 1982); Elaine Tyler May, Great Expectations: Marriage and Divorce in PostVictorian America (Chicago, 1980); and idem, "In-Laws and Out-Laws: Divorce in New Jersey, 1890-1925," in Mary R. Murrin, ed., Women in New Jersey History (Trenton, NJ, 1985), 31-41.

THE ANNALS OF IOWA 50 (Winter 1991). (C) The State Historical Society of Iowa, 1991. 
rewards, involved in studying such records. The records are plentiful, for in spite of Iowa's bucolic image, created in part by Grant Wood's paintings and the prairie novels of Bess Streeter Aldrich and Hamlin Garland, many Iowans divorced. In 1930 the state's divorce rate ranked twenty-third in the nation. In Linn County, 4,758 divorces were granted between 1928 and 1944 . Of these, 3,796 , or nearly 80 percent, went to women, while 962 , or slightly more than 20 percent, went to men. ${ }^{2}$

BASIC DETAILS of each Linn County divorce were recorded in a register titled Record of Divorces, 1928-1944. The register includes names, nationality, race, number of prior marriages, date of marriage, grounds for divorce, date of divorce, and whether alimony was awarded. From a researcher's viewpoint, it is unfortunate that the divorce register omits numbers of children involved and decisions concerning custodial parents. In addition, child support awards are recorded only in marginal notations. The register also neglects to specify which cases were annulments rather than divorces. Annulments can be identified only by the ground listed-consanguinity, impotence, bigamy, insanity, or either party being under legal age at the time of marriage. ${ }^{3}$

Further information concerning each couple listed in the register can be found in a case file, which includes a divorce petition, such court orders as writs of attachment and injunctions, a transcript of the couple's divorce hearing, and a divorce decree. These case files, which are not easily accessible to researchers, have a number of deficiencies. In particular, case

2. State divorce rates are found in Alexander A. Plateris, One Hundred Years of Marriage and Divorce Statistics: United States, 1867-1967 (Rockville, MD, 1973), 34-35. Numbers of Linn County divorces are from Record of Divorces, 1928-1944, Linn County, Iowa, Linn County Courthouse, Cedar Rapids, Iowa. I hand-counted the figures. I chose the period 1928 to 1944 for what it might reveal about changes in numbers of divorces during the depression years. The data showed no significant rise or drop in divorces during those years, but they did reveal the difficulties of analyzing divorce cases. For a description of Linn County and its major city, Cedar Rapids, see Ernie Danek, Tall Corn and High Technology (Woodland Hill, CA, 1980).

3. Impotency was the most commonly cited cause for annulments. See, for example, Cases \#55321, 40958, and 48869, Record of Divorces. Names of litigants have been omitted to protect the privacy of their families. 
file documents fail to record routinely the presence or absence of children or child support awards. One wife received custody of the couple's infant daughter, but no mention is made of child support although she had specifically requested it. In another case, the register indicated that child support had been awarded, but case file documents give no indication that a support order existed. ${ }^{4}$

Another problem with Linn County case files is their failure to record the occupations of litigants except in an occasional passing mention. In asking for custody of a seven-month-old daughter and support for the child, one wife stated that her husband worked at a starch factory in Cedar Rapids where he earned five dollars per day. Another wife testified that her husband earned $\$ 165$ per month working as a railroad switchman, and one that her husband worked for the Lock Joint Pipe Company in Kansas City. References to women's employment were even more sparse, but occasionally a husband remarked that his wife worked as a housekeeper or in another job. In other cases, wives noted that they had been employed during the marriage, but seldom specified their jobs. ${ }^{5}$

In addition to discrepancies and omissions, case files frequently lack enough information for a reader to draw a reasonable conclusion about certain cases. In one sketchy set of records, a woman charged her husband with cruelty, but gave no details or substantiating incidents from their six-year marriage. ${ }^{6}$ As a result, the occurrences that drove her toward the divorce court are unknown. In a similar case, a husband petitioned for divorce from his wife on the ground of cruelty, but failed to offer substantiating examples. Yet on April 10, 1943, only nineteen days before their twenty-seventh anniversary, he received a divorce. Although his wife was the guilty party, the court awarded her alimony of ten dollars per week and title to

4. Cases \#39068 and 50739, Record of Divorces. Such variation in documents and resulting interpretations often led to debates about whether divorce law helped or hurt women. For such a debate, see Claude D. Stout, "The Legal Status of Women in Wisconsin," Marquette Law Review 14 (February/June 1930), 155-65; and Julia B. Dolan, "Another Version of the Legal Status of Women in Wisconsin," Marquette Law Review 15 (April 1931), 139-57.

5. Cases \#39068, 37932, 41557, 42003, and 39124, Record of Divorces.

6. Case \#42022, Record of Divorces. 
their house and household goods. The records do not indicate whether the husband offered this settlement, if the wife asked for it, or if the judge initiated it. ${ }^{7}$

Case file documents also leave a good deal unexplained in another far more intricate suit that eventually resulted in two divorce decrees. The husband, who had been married four previous times, and the wife, who had been married six previous times, had obtained a divorce on January 16, 1940, on an unspecified ground. They remarried on February 23, 1940. In late 1940 the wife applied for a divorce, testifying that her husband beat her, cursed her, and called her "all manner of vile names." Her husband responded that she drank to excess, had threatened to kill him, had thrown dishes at him, and had "made a general nuisance of herself." The judge awarded the wife a divorce and one fifty-dollar alimony payment. A few days later, the former wife and husband were back in court asking to have the decree set aside. The husband then petitioned for a divorce from his wife. On December 4, 1940, the same judge ruled for the husband. ${ }^{8}$ One can only guess whether this was a case of a tempestuous relationship with numerous breakups and reconciliations, or one in which a vindictive husband tricked his wife in order to save face and fifty dollars by getting a divorce himself.

Clearly, it is difficult to draw accurate conclusions about divorce petitions and decrees from such inconsistent, incomplete data. Answers to important questions concerning child support and which occupational groups most frequently divorced remain uncertain.

PEOPLE'S TRUE REASONS for divorcing their spouses are likewise almost impossible to divine. Linn County divorceseekers had a choice of only six grounds during this period. They chose the ground that most closely approximated their situations, was the least damaging to everyone concerned, or was the most likely to persuade a judge to give them a divorce and a favorable settlement. Consequently, their divorce petitions

7. Case \#55585, Record of Divorces.

8. Case \#52678, Record of Divorces. 
were legal documents rather than honest, complete stories about their marriages.

The six grounds available to residents of Linn County were well established and widely accepted because they had developed over nearly a century. When the United States Congress created the district of Iowa as part of the Territory of Michigan in 1834, Iowa fell under the jurisdiction of the Ordinance of 1787, which specified impotency, adultery, extreme cruelty, and willful desertion for three years as grounds for divorce. In 1836 Iowa became part of the Territory of Wisconsin; then the territorial legislature granted divorces. ${ }^{9}$

When Iowa became a territory in its own right in 1838 , legislators specified only impotency and adultery as grounds for divorce. Iowa's Revised Statutes of 1842-43 listed eight grounds for divorce: impotency, bigamy, adultery, desertion for one year, conviction of a felony or infamous crime, habitual drunkenness, cruel and barbarous treatment endangering the life of spouse, and indignities rendering a spouse's situation intolerable. In 1845 an amendment added a ninth cause-an omnibus clause that permitted judges to grant divorces "when it shall be made fully apparent to the satisfaction of the court, that the parties cannot live in peace or happiness together, and that their welfare requires a separation between them. ${ }^{\prime 10}$

When Iowa achieved statehood in 1846, those provisions remained in force. In 1851, however, the legislature reduced the number of grounds to eight by deleting the indignities clause. Four years later, a conservative legislature stipulated that only adultery, conviction of a felony, impotency, and desertion for three years were grounds for divorce. But in 1858 the legislature restored all of the grounds listed in the 1851 Code except the omnibus clause, and compromised on the desertion clause, with desertion for two years being grounds for divorce. Legislators in subsequent years tinkered only slightly with the provisions. The Code of 1873 included an amended list of grounds,

9. See Ruth A. Gallaher, Legal and Political Status of Women in Iowa (Iowa City, 1918), 17-21.

10. 1839 Iowa Territorial Statutes $189-91 ; 1843$ Iowa Territorial Revised Statutes 238-39; 1841-42 Iowa Territorial Acts 87; 1845 Iowa Territorial Acts 23. 
adding prior pregnancy of a wife by a man other than her husband, but omitting impotency and bigamy. ${ }^{11}$

In 1928, then, Iowa had six grounds for divorce, five of which were long-term and customary reasons: adultery, desertion, conviction of a felony, habitual drunkenness, and cruel and inhuman treatment. ${ }^{12}$ Because the sixth ground-prior pregnancy of a wife-was seldom used, lowans essentially had only five grounds available to them. Whatever conditions terminated their marriages, petitioners had to fit them into the rubric of these charges.

Linn County's divorce register for the years 1928 through 1944 indicates that petitioners' choices of grounds were similar to the choices made by Americans nationwide. The majority of Linn County litigants leaned toward broad, relatively nondamning grounds, especially cruelty. In a randomly selected sample of nine hundred cases from the divorce register, 85 percent of petitioners pleaded cruelty; nearly 88 percent of women used this charge, while nearly 78 percent of men did so. ${ }^{13}$ It is likely that a number of divorcing couples colluded in choosing this ground rather than harsher grounds, such as adultery or alcoholism. Although collusion concerning grounds can seldom be proven, the possibility of its existence demands that records be read with a critical eye.

Cruelty had become an increasingly attractive ground over the years because the Iowa Supreme Court had broadened its definition. In 1871 the court had ruled that a wife who charged her husband with cruelty could be granted a divorce only if his actions threatened her physical well-being. "Mere turbulence of temper, petulance of manner" did not count, nor did "every

11. Code of Iowa (1851) § 1482; 1854-55 Laws of Iowa 112; 1858 Laws of Iowa 97-98, 236; Code of Iowa (1873) §§ 2223-24; Annotated Code of lowa (1897) §§ 3174-75; Code of Iowa (Supp. 1913) §§ 3174-75. See also John E. Briggs, History of Social Legislation in lowa (Iowa City, 1915), 89-90.

12. Isabel Drummond, Getting a Divorce (New York, 1931), 93-96. For an overview of changing divorce law, see Lawrence M. Friedman, "Rights of Passage: Divorce Law in Historical Perspective," Oregon Law Review 63 (1984), 649-69; Max Rheinstein, Marriage Stability, Divorce, and the Law (Chicago, 1972); and Roderick Phillips, Putting Asunder: A History of Divorce in Western Society (Cambridge, 1988).

13. The sample of nine hundred cases, which I hand-counted, was derived from Record of Divorces. 
slight touching of the wife by the husband, even in anger" constitute grounds for a divorce. But in 1889 the Supreme Court reversed the earlier decision, declaring that "cruel or inhuman treatment" need not be physical; even repeated statements by the husband that the wife was unchaste could justify divorce on the ground of cruelty because his words could create a detrimental mental state that was damaging to her health. ${ }^{14}$

One petitioner who took advantage of the enlarged construction of cruelty was a man who sued his wife for divorce in 1928. He charged cruelty because she had falsely assured him that she had sufficient funds to convert the top floor of his house into a rental unit. He married her, engaged plumbers and others to do the necessary renovations, and presented the bills to her. She stalled by saying that she preferred to withdraw her funds after the end of the current interest period. Eventually, she admitted that she had lied about having capital to invest in the house. She then refused to cosign a bank loan to pay the bills. A subsequent divorce decree ensured that his house would be free from any claims by her. ${ }^{15}$

The second most popular ground was desertion. Of the sample of nine hundred cases, 10 percent of Linn County petitioners claimed desertion; 8 percent of women and nearly 19 percent of men did so. In one desertion case, a woman sued her husband for divorce in 1930, seven years after he had deserted her and their two children. The documents fail to disclose either her reasons for waiting so long to obtain a divorce or the judge's reasons for ruling that she could remarry immediately rather than fulfilling the one-year waiting period required by Iowa law. The woman probably had recently become romantically involved. Marriage would give her children a home, a high priority for most judges who often allowed immediate remarriage in such cases. A curious case of desertion involved the mother of a ten-year-old boy who accused her husband of refusing to

14. Many cruelty decisions are reviewed in Code of Iowa (Supp. 1913) § 3174. See also Gallaher, Legal and Political Status of Women, 67-68. A similar trend occurred in other parts of the country as well. See, for example, Jane Turner Censer, "Smiling Through Her Tears': Ante-Bellum Southern Women and Divorce," American Journal of Legal History 25 (January 1981), 24-47.

15. Case \#38441, Record of Divorces. 
supply her with "sufficient necessaries and comforts," being habitually drunk, and, by his behavior, forcing her to leave him. Because he had never asked her to return, she argued that "such conduct on his part amounted to legal desertion." The court apparently agreed, for it granted the divorce. ${ }^{16}$

Only slightly more than one percent of the sampled Linn County petitioners used the ground of conviction of a felony; 1.5 percent of women and 0.5 percent of men used this charge. Felony cases tended to be cut-and-dried, probably because the evidence of a spouse's incarceration was indisputable. One wife with three young children under the age of three testified that her husband was in an Iowa reformatory because he had committed an unnamed felony. She requested custody of the three children, fifty dollars per month child support, and permission to remarry before the end of the one-year waiting period. She got custody of the children, but her husband's argument that he was unable to earn money while in jail was a telling one; she received neither alimony nor child support. The divorce decree also omitted any mention of remarrige. ${ }^{17}$

Another one percent of sampled Linn County petitioners accused their mates of being habitual drunkards; nearly 2 percent of women and 0.5 percent of men used this ground. In one instance, a mother of three young children was divorcing her husband for the second time. She explained that she had remarried him because he had promised to quit drinking. But he continued to drink heavily; he went on "sprees" and beat her. She received a divorce and custody of the children but no child support. In another case, a husband who stated that his wife drank, cursed at their three daughters, and struck him received a divorce and custody of the children. ${ }^{18}$

Slightly less than one percent of sampled Linn County petitioners charged adultery; 0.6 percent of women and 1.6 percent of men did so. In a 1930 case, for example, a wife charged her husband with abandoning her and their two children, threatening 'her with violence, refusing to support her

16. Cases \#52681 and 53723, Record of Divorces.

17. Case \#42003, Record of Divorces. In most felony cases, the crime went unnamed. See, for example, Case \#57028, Record of Divorces.

18. Cases \#50739 and 52631, Record of Divorces. 
and the children, and committing adultery with a woman he illegally "transported" from Illinois to California for "immoral purposes." She won a divorce, custody of the children, and ten dollars per week child support. In an especially harsh petition, a husband charged his wife with adultery and with having been "an inmate of a house of prostitution" during recent months. He received custody of their three children, but the judge allowed her visitation rights. Although it may seem curious that the judge allowed a woman of her reported character to visit her children, many judges believed that even errant mothers had important bonds with their offspring. ${ }^{19}$

In the Linn County sample, every petitioner cited specific charges of cruelty, abuse, or desertion. Although such factors as rising expectations of marriage or a determination to have a companionate marriage may have contributed to the disintegration of their marriages, petitioners had to frame their charges to fall within the limits of Iowa divorce law rather than exploring and recording the full range of reasons for requesting a divorce.

DIVORCE-SEEKERS, of course, typically presented only one side of the story. In most cases, there was little opportunity for defendants to present their own complaints unless they countersued. Also, petitioners were often likely to paint the worst possible picture of their marriages and spouses in order to persuade a judge to grant them a divorce and award them a favorable settlement.

Conflicting testimony in contested divorce suits demonstrates the folly of taking a petitioner's view of marital failure and a spouse's sins as truth. In 1928 a woman who had been married six times before sued her husband, who had been married twice before, on the ground of cruelty. She testified that he cursed at her and refused to give her money. In his crosspetition, her husband maintained that she nagged, complained, and wanted a home in Cedar Rapids rather than in Clinton where he worked. He added that she cursed at him and ha-

19. Cases \#41557 and 46669, Record of Divorces. For another example of a husband charging his wife with adultery, see Case \#55725, Record of Divorces. 
rassed him to the point that it impaired his health. She got a divorce and two hundred dollars while he paid the court costs and attorney's fees. ${ }^{20}$

In another 1928 case a husband stated that his wife associated with other men much to his "humiliation and grief." He wanted a divorce, their house and automobile, and all household goods. His wife responded that because she had been employed and had done all the housework as well, she was entitled to an equal portion of their property and household goods. She added that her husband had physically abused her, made her so nervous that it "spoiled her peace of mind and her appetite," cancelled her charge account, and caused her to lose her job. On May 22, 1929, the husband received a divorce and their property, automobile, and household goods. ${ }^{21}$

In other contested cases, defendants protested charges so effectively that they, instead of the original plaintiffs, received divorces and favorable judgments from courts. In 1929 a woman charged her husband with striking, abusing, and choking her. She asked for alimony and a writ of attachment against her husband's property. He denied her allegations and charged her with cohabiting with other men and currently living with an Iowa City man. After a protracted hearing, the judge ruled for the husband. In another case, a husband who had been married twice before charged his wife, who had been married once before, with calling him a "son of a bitch" and a "dirty dog," neglecting her household duties, and threatening to strike him with a poker. She countered that he had gone out with other women, knocked her into a ditch, and attacked her at a dance. The judge ruled for the wife. ${ }^{22}$

DESPITE THEIR MANY DISCREPANCIES and difficulties, divorce records often contain information that is useful and worthy of further study. The Linn County register, for example, affirms the growing democratization of divorce, a process that was occurring all over the nation.

20. Case \#37932, Record of Divorces.

21. Case \#39124, Record of Divorces.

22. Cases \#39792 and 42022, Record of Divorces. 
According to the register, people from many ethnic and racial groups sought divorces. Although the majority of Linn County litigants listed their nationality as American, others apparently failed to understand the concept because they responded that their nationality was Yankee, Iowan, Kansan, Missourian, Jewish, white, "redskin," or unknown. Bohemians, who were a sizable group in Cedar Rapids, were also the dominant ethnic group to request divorces in Linn County; they accounted for approximately 5.5 percent of sampled litigants. Germans composed slightly over 5 percent of sampled litigants, while English and Irish numbered nearly 4 percent each. Handfuls of other litigants identified themselves as African, AfroAmerican, Assyrian, Belgian, Canadian, Czechoslovakian, Danish, Dutch, French, Greek, Hungarian, Italian, Lithuanian, Mexican, Norwegian, Polish, Russian, Scotch, Serbian, Scandinavian, Scotch-Irish, Swedish, Swiss, Syrian, or Welsh.

Race was not always clearly recorded in the register, but it appears that sixty-one African-American couples divorced between 1928 and 1944 . Wives obtained forty-three of these divorces, husbands eighteen. Two interracial couples obtained divorces. In both cases, white wives sued black husbands.

Another significant Linn County statistic is the number of prior marriages of each litigant, which hints at the emergence of multiple divorce in the United States. Among female litigants in the sample, slightly less than 18 percent had been married once before, 3.6 percent had been married twice before, and almost 1 percent had been married three times or more before. The statistics for male litigants are nearly identical. One woman and one man admitted to six prior marriages.

It is impossible to determine whether death or divorce terminated these litigants' previous marriages, but surely some had ended in divorce. In 1938 an article in Harper's Monthly confirmed the existence of multiple divorce. The female author, who had recently married for a third time, analyzed her two divorces and speculated on reasons for multiple divorce. ${ }^{23}$ Although multiple divorces would have skewed the divorce rate, analysts generally overlooked the phenomenon. The

23. "Thrice Married," Harper's Monthly 176 (April 1938), 545-53. 
history and development of multiple divorce is still largely unstudied.

The Linn County case sample also indicates that a significant number of marriages were extremely brief in duration. Twelve percent of sampled divorce cases involved marriages of less than two years duration. One woman requested a divorce from her husband on the ground of cruelty because he had, according to her, used violent language, threatened her life, and impaired her health by constantly pointing out her faults. They had married on October 25, 1932, and were divorced on November 8, 1933. In 1939 a wife charged her husband with cruelty because he had "damned and vilified" and struck her. They had married on January 12,1938, and were divorced on September 30, 1939. ${ }^{24}$

Yet other data from the divorce register demonstrate that alimony and child custody awards, which lay entirely in the hands of judges, were something of a lottery. Usually, women received such awards far more often when they were plaintiffs.

Principles of judicial discretion and alimony awards had undergone long development in Iowa. The Iowa Code of 1838-39 stated that in divorce cases based on a wife's adultery "the husband shall have the personal estate for ever, and the real estate of the wife," but a court could "allow for her subsistence" out of the couple's holdings as it saw fit. If the wife was deemed the innocent party, she received the property she owned at the time of marriage and could expect the court to order alimony payments up to one-half of her husband's income. The Code of 1842-43 put additional power into the hands of judges by ruling that courts would decide both property matters and alimony payments. Judges were still expected to restore an innocent wife's property to her and to grant alimony payment to wives who were innocent parties to divorces. ${ }^{25}$

Subsequent legislation reaffirmed judicial discretion. The Iowa Code of 1851 stated that the court could make decisions regarding the "property of the parties and the maintenance of

24. Cases \#45509 and 52353, Record of Divorces.

25. 1839 Iowa Territorial Statutes 190; and 1839 Iowa Territorial Revised Statutes 239. 
the wife as shall be right and proper." Under this rule, courts could, and did, give a share of a husband's property to a wife as alimony, thus allowing her more freedom to manage her own affairs than she would have had with payments. In addition; judges sometimes awarded even guilty wives property settlements and alimony awards. The Code of 1873 further enlarged the prerogatives of judges by providing that "the court may order either party to pay the clerk a sum of money for the separate support and maintenance of the adverse party and the children, and to enable such party to prosecute or defend the action." Because of this provision, in 1882 a husband received alimony of three hundred dollars although he was at fault. ${ }^{26}$

In the Linn County sample, only 29 percent of litigants received alimony and 4 percent received child support in place of alimony; 67 percent received neither alimony nor child support. In cases involving alimony awards, 87 percent of plaintiffs were women. This finding suggests that women were still more likely to get alimony if they were the innocent parties in divorce actions.

In addition to data from the divorce register, individual case files are also useful. They flesh out statistical data and expose aspects of divorce overlooked by the register. For instance, case files show that a number of divorced persons in Linn County remarried in less than one year, the waiting period required by lowa law. According to the documents in seventy-seven randomly selected case files, fourteen people expressed interest in circumventing the one-year waiting requirement. In one instance, a wife and mother of two children accused her husband of "consorting" with another woman and refusing to support his family. On June 20,1944, she received a divorce, custody of the children, and six dollars per week child support. Six days later, she was back in court, claiming that her former husband had "absconded from the state $^{\prime \prime}$ and was not making his support payments. She asked the court's permission to marry an employed Cedar Rapids man who would provide a home for her and her children. There is no evidence that the judge raised any questions about

26. Code of Iowa (1851) § 1485; Code of Iowa (1873) § 2226; Gallaher, Legal and Political Status of Women, 69-73. 
the timing of the incidents in this case. It is likely that he was pleased to see a new family in the making and thus gave her permission to remarry immediately. ${ }^{27}$

A number of other cases also suggest that many judges were more concerned about creating new families and providing two parents for children than they were about the legalities of the prescribed waiting period. A 1932 decree that gave a father custody of the couple's two children also gave him permission to remarry at any time although there is no evidence in the records that he requested such a waiver. ${ }^{28}$ In a 1942 divorce suit, the court also condoned rapid remarriage. In this case, a wife sued her common-law husband for a divorce on the ground of alcoholism. For an unexplained reason, the judge ordered the couple's two children to remain in the custody of the juvenile court until further notice. The divorce was granted on October 5, 1942. Although neither party received permission to remarry, the wife reappeared in court on March 4, 1943, to inform the judge that she had married a defense-plant worker from Burlington, Iowa. She also requested custody of the two children. Again without questioning the timing of these events, the judge remanded custody to her and her new husband. ${ }^{29}$

Unarguably, the Linn County divorce register and case files for the years 1928 to 1944 provide useful data and fascinating stories regarding divorce during these years. Certainly, divorce records beckon researchers and raise significant questions that demand extensive analysis. Still, perhaps the most important point to be derived from the Linn County records is that such documents must be used with caution because they only partially reveal the underside of marriage. To take them at face value is to ignore their difficulties-and to distort conclusions about such crucial matters as people's attitudes toward marriage and their reasons for divorce.

27. Case \#56132, Record of Divorces.

28. Case \#44499, Record of Divorces.

29. Case \#55257, Record of Divorces. 
Copyright of Annals of Iowa is the property of State of Iowa, by \& through the State Historical Society of Iowa and its content may not be copied or emailed to multiple sites or posted to a listserv without the copyright holder's express written permission. However, users may print, download, or email articles for individual use. 